\title{
Komunikasi Interpersonal Kyai dan Santri dalam Pesantren Modern di Tasikmalaya, Sebuah Pendekatan Interactional View
}

\author{
Nadia Wasta Utami \\ Program Studi Ilmu Komunikasi, Universitas Islam Indonesia, Yogyakarta \\ syihabnadia@gmail.com
}

\begin{abstract}
Abstrak
Kyai-santri dalam system yang dinamakan pesantren, memiliki hubungan yang unik yang mana terbentuk dari proses interaksi terus-menerus dalam proses ajar-mengajar maupun dalam keseharian. Dalam relasi ini, kyai dan santri pada umumnya tetap menggunakan komunikasi interpersonal sebagai pilihan utama dalam berinteraksi. Tulisan ini bertujuan untuk mengupas komunikasi interpersonal antara kyai dan santri dalam pesantren modern di Tasikmalaya dengan menggunakan pendekatan interactional view milik Watzlawick. Metode yang digunakan adalah kualitatif deskriptif dengan teknik pengambilan data berupa studi pustaka, observasi dan wawancara. Dari penelitian yang dilakukan ditemukan bahwa, kyai dan santri dalam sebuah system pesantren, tidak bisa tidak melakukan komunikasi verbal dan nonverbal; baik kyai maupun santri tidak hanya sekadar menyampaikan konten namun juga memperhatikan relasi dengan memakai cara-cara tertentu; penyampaian pesan bersifat symmetrical dengan didominasi oleh kyai; dan terdapat banyak aturan tidak tertulis yang mewarnai komunikasi santri-kyai dengan tujuan menunjukkan rasa hormat santri pada kyainya.
\end{abstract}

Keyword :Kyai, Santri, pesantren, komunikasi interpersonal, interactional view

\begin{abstract}
Kyai-santri in a system called pesantren, has a unique relationship which is formed from the process of continuous interaction in teaching-learning process and in daily life. In this relation, kyai and santri generally keep using interpersonal communication as the main choice in interaction. This paper aims to explore the interpersonal communication between kyai and santri in modern pesantren in Tasikmalaya by using Watzlawick's interactional view approach. The method used is qualitative descriptive with data retrieval technique namely literature study, observation and interview. The research found that, kyai and santri cannot not do communication: both verbal and non verbal; both kyai and santri not only communicate the content but also have a unique way of building relationships; message delivery type is symmetrical with dominated by kyai; and there are many unwritten communication rules of santri-kyai showing the santri's respect for their kyai.
\end{abstract}

Keyword :Kyai, Santri, pesantren, interpersonal communication, interactional view 


\section{PENDAHULUAN}

Pesantren merupakan suatu institusi sosial keagamaan yang menjadi tempat menimba ilmu agama Islam. Pesantren juga merupakan lembaga pendidikan tertua dan asli Indonesia. Seiring dengan perkembangan zaman, pesantren kini mengalami perubahan sehingga banyak pesantren yang menamakan dirinya sebagai pesantren modern. Pesantren modern, dibedakan dengan pesantren tradisional, mengacu pada pesantren yang menyatukan pengajaran Islam dan pendidikan umum. Istilah pesantren modern ini muncul beriringan dengan berdirinya Pondok Pesantren Gontor yang tidak hanya menekankan pada pembelajaran agama, tapi juga pada ilmu-ilmu umum namun tetap menggunakan sistem asrama atau pondok bagi para santrinya (Dhofier, 2005).

Kini, pesantren modern menjadi salah satu pilihan favorit bagi mereka yang ingin menyeimbangkan ilmu agama dan ilmu umum dalam satu tempat. Hal ini mengakibatkan meningkatnya jumlah pesantren modern yang ada di Indonesia. Setidaknya ada 179 pesantren modern yang salah satu basis lokasinya adalah di Kota Tasikmalaya (Luthfiani, 2008). Tasikmalaya mahsyur dengan sebutan Kota Santri. Selain karena memiliki lebih dari 700 pesantren yang tersebar di wilayahnya, sebutan Kota Santri semakin melekat pada Tasikmalaya dengan disertakannya gambar kubah masjid pada lambang Tasikmalaya, sebagai perwujudan dari citra Kota Santri, dan dicanangkannya berbagai program yang mendukung pendidikan di pesantren ${ }^{1}$.
Pesantren, kyai, dan santri merupakan tiga hal yang tak bisa dipisahkan satu sama lain. Tampaknya tidak ada seorang pun yang memungkiri bahwa peran kyai dan santri dalam proses pertumbuhan dan perkembangan pendidikan di Indonesia sangatlah signifikan. Hubungan antara kyai dan santri terlihat dari kegiatan utama yang dilakukan dalam pesantren yaitu pengajaran. Melalui kegiatan ajar-belajar, seorang kiai mengajarkan pengetahuan keislaman kepada para santrinya yang akan meneruskan proses penyebaran islam. Di luar kegiatan belajar pun, santri dan kyai kerap terjadi berbagai komunikasi yang khas dan penuh ta'dzim seorang murid pada gurunya. Berangkat dari hubungan kyai dan santri tersebutlah, maka komunikasi yang kental dalam pesantren adalah komunikasi tradisional dan komunikasi interpersonal yang mengutamakan tatap muka secara langsung.

Silaturahmi santri kepada kyai menjadi satu bentuk khas dari komunikasi tradisional. Komunikasi tatap muka juga terjadi pada pengajian yang diadakan di pesantren. Pengajian yang diadakan para kyai dan dihadiri oleh para santri ini menjadi satu-satunya komunikasi diantaranya. Komunikasi tatap muka adalah pilihan utama bagi para santri sowan atau sekedar silaturahim kepada kyainya. Namun masih kah hal tersebut relevan dengan perkembangan teknologi komunikasi dan bentuk pesantren modern yang ada? Untuk itu, tulisan ini akan membahas lebih lanjut mengenai bagaimana komunikasi interpersonal yang terjadi antara kyai dan santri dalam

${ }^{1}$ Lebih lanjut lihat www.tasikmalayakota.go.id 
pesantren modern dengan pendekatan teori interactional view.

Penelitian ini menggunakan metode kualitatif deskriptif karena bertujuan untuk memaparkan serta mendeskripsikan bagaimana komunikasi interpersonal dalam hubungan kyai dan santri dalam pesantren modern di Tasikmalaya. Penelitian ini tidak dalam rangka menunjukkan hubungan antar variable atau menguji hipotesis atau predisksi dari variable-variabel tersebut (Rahmat, 2001). Data yang dikumpulkan dalam penelitian ini didapat dari beberapa Teknik diantaranya seperti studi pustaka, observasi dan wawancara. Studi pustaka digunakan dengan mengutip, juga mencatat beberapa pendapat atau pun konsep dari ahli dalam buku, literatur maupun dokumen-dokumen yang bersesuaian dengan objek serta kajian penelitian. Observasi dilakukan pada bagaimana keseharian serta komunikasi yang terjalin antara kyai dan santri pada beberapa pesantren modern di tasikmalaya seperti Pondok Pesantren Sukahideng, Sukamanah dan Cipasung. Sedangkan wawancara melengkapi data dengan langsung bertanya pada pengurus dan santri dari pondok pesantren tersebut.

\section{HASIL DAN PEMBAHASAN}

Interactional view merupakan teori yang dilahirkan dari pemikiran Paul Watzlawick, seorang Clinical Associate Professor Department Psychiatry and Behavioral Sciences, Stanford University of Medical Center dan principal investigator pada Mental Research Institute (MRI) Palo Alto. Waztlawick mengandaikan bahwa sebuah keluarga merupakan sebuah sistem. Hal ini berarti anggota keluarga merupakan bagian sistem yang mau tidak mau harus saling berkait dan berhubungan sehingga sistem dapat berjalan dengan baik. Sebuah keluarga dapat diumpamakan sebagai sebuah system dimana setiap bagiannya saling terhubung dan berikatan. Watzlawick menyatakan bahwa setiap anggota merupakan potongan system dan saling terhubung dan terikat menjadi satu dalam sebuah kesatuan system (Griffin, 2006). Menurut Watzlawick, salah satu hal yang dapat merekatkan sebuah sistem adalah komunikasi. Komunikasi menjadi hal yang sangat penting karena keberadaannya menjadi sebuah indikasi bahwa suatu sistem berjalan pada jalur yang tepat.

Interactional view Watzlawick ini sangat dekat dengan konsep komunikasi interpersonal yang mengutamakan adanya interaksi anggota-anggota dalam system. Sebagaimana namanya, interpersonal yang terdiri dari prefix inter yang berarti diantara dan person yang berarti manusia maka secara bahasa komunikasi interpersonal bermakna komunikasi antara manusia. In one sense, all communication happens between people, yet many interactions don't involve us personally. Communication exist on a continuum from impersonal to interpersonal (Wood, 2010). Secara singkat, West \& Turner (2010) berpendapat bahwa interpersonal communication referred to face-toface communication between people. Maka Miller \& Steinberg dalam Pearson et al, (2003) mendefinisikan komunikasi interpersonal sebagai communication that occurs within interpersonal relationships. Sedangkan interpersonal relationships dimaknai sebagai associations between 
two people who are interdependent, who use some consistent patterns of interaction, and who have interacted for an extended period of time. Pengertian ini dijelaskan lebih detail dengan beberapa elemen berikut (Pearson et al, 2003):

1. Interpersonal relationships include two or more people. Biasanya, hubungan interpersonal hanya terdiri dari dua orang (dua orang yang berkencan, single parent dan anaknya, sepasang suami istri, dua sahabat karib, dua orang rekan kerja). Namun hubungan interpersonal juga dapat melingkupi lebih dari dua orang (sebuah keluarga, sekelompok sahabat, suatu grup sosial). Pendapat yang lain justru memahami keterkaitan antara interpersonal komunikasi dalam media massa, organisasi hingga kelas (West \& Turner, 2010).

2. Interpersonal relationships involve people who are interdependent. Interdependence merujuk pada orang-orang yang saling tergantung dan mempengaruhi satu sama lain.

3. Individuals in interpersonal relationships use some consistent patterns of interaction. Pola-pola ini terdiri dari perilaku yang muncul pada berbagai situasi dan biasanya merupakan perilaku yang unik.

4. Individuals in interpersonal relationships generally have interacted for some time. Suatu hubungan interpersonal tidak bisa terjadi hanya karena satu kali interaksi saja, meskipun memang komunikasi interpersonal bisa terjadi dalam berbagai periode waktu: beberapa terjadi hanya dalam waktu yang singkat, yang lain terjadi terus- menerus sepanjang hidup.

Dari pengertian interpersonal communication dan interpersonal relationship di atas maka hubungan antara kyai dan santri yang menjadi objek dalam tulisan, ini dapat dikategorikan pula sebagai suatu hubungan interpersonal yang berujung pada terjadinya komunikasi interpersonal. Ide awal Watzlawick yang berpikiran bahwa interactional view merupakan suatu interaksi dalam system yang berupa keluarga, menjadikan pesantren menjadi tempat penelitian yang menarik karena relasi kepatuhan antara santri dengan kyai mirip dengan relasi kepatuhan seorang anak dengan orang tua. Relationships antara kyai dan santri tentu saja terjadi antara dua orang yang ada dalam system yang bernama pesantren. Hubungan kyai dan santri juga saling ketergantungan dan mempengaruhi satu sama lain dimana jika tak ada santri, maka tak akan ada kyai dan sebaliknya jika kyai tak ada, maka term santri pun tak akan pernah muncul. Selanjutnya, perilakuperilaku yang muncul dalam interaksi keseharian kyai dan santri membentuk suatu pola-pola perilaku yang unik dan mungkin tak akan bisa ditemui dalam lembaga pendidikan mana pun ${ }^{2}$. Dan yang terakhir, interaksi komunikasi interpersonal antara keduanya tak hanya terjadi sekali atau dua kali namun terus berlangsung hampir tiap hari dalam

\footnotetext{
${ }^{2}$ Lebih lanjut akan dibahas dalam aksioma interactional view
} 
pengajian rutin yang diadakan pesantren bahkan terkadang berlangsung hingga seumur hidup karena sang santri menjadi bagian dari keluarga kyai dengan menikahi putri sang kyai.

\section{Komunikasi Interpersonal Kyai dan Santri Dalam Pesantren Modern}

Pondok pesantren modern adalah suatu pengembangan tipe pesantren yang orientasi belajarnya cenderung mengadopsi seluruh sistem belajar layaknya sekolah umum dan meninggalkan sistem belajar tradisional ala pesantren. Sistem belajar modern ini sangat tampak dari pemakaian kelas-kelas belajar baik dalam bentuk madrasah maupun sekolah. Kurikulum yang dipakai adalah kurikulum sekolah atau madrasah yang berlaku secara nasional. Santrinya ada yang menetap ada yang tersebar di sekitar desa itu. Kedudukan para kyai sebagai koordinator pelaksana proses belajar mengajar dan sebagai pengajar langsung di kelas. Perbedaanya dengan sekolah dan madrasah terletak pada porsi pendidikan agama dan bahasa Arab lebih menonjol sebagai kurikulum lokal (Dhofier, 2005).

Secara umum, pondok pesantren modern di Tasikmalaya menyediakan sekolah negeri atau swasta mulai dari SLTP, SMU hingga perguruan tinggi. Terkadang, sekolah tersebut masih dalam satu yayasan dengan pondok pesantren, namun ada juga yang terpisah. Pada umumnya, pesantren modern yang terintegrasi dengan sekolah baik negeri maupun swasta, memiliki kurikulum dan jadwal pengajian yang disesuaikan dengan jadwal sekolah.
Tipe pesantren modern ini rupanya sedikit banyak mempengaruhi komunikasi interpersonal sang kyai dan santrinya. Frekuensi pertemuan dan komunikasi menjadi lebih terbatas dibandingkan dengan pesantren tradisional yang tidak terintegrasi dengan sekolah. Sebelum membedah komunikasi interpersonal kyai dan santri, perlu dipahami terlebih dahulu apa makna dari komunikasi interpersonal. Watzlawick dalam Griffin (2006) menjabarkannya dalam beberapa Aksioma komunikasi interpersonal berikut :

\section{One cannot not communicate}

Komunikasi merupakan sebuah proses yang akan selalu terjadi dalam sebuah system. Ketika kita berada dalam sebuah sistem, sangat tidak mungkin bagi kita untuk menolak komunikasi karena meskipun kita tidak berkomunikasi secara verbal namun sikap penolakan kitapun merupakan bentuk komunikasi secara nonverbal. Watzlawick mencontohkan aksioma pertamanya ini dengan interaksi antara seorang ibu dan anaknya yang baru saja pulang dari pesta. Si ibu bertanya, "Bagaimana pestanya tadi apakah menyenangkan?" Si anak yang merasa sama sekali tidak senang dengan pestanya tadi sangat malas untuk bercerita pada ibunya. Alih-alih bercerita, ia langsung melenggang masuk kamar tanpa sepatah kata pun. Meskipun si anak tak berkata apa-apa, ibu langsung mengerti dari bahasa tubuh dan mimic anaknya bahwa pesta tadi tak berjalan seperti yang anaknya harapkan.

Maka komunikasi verbal di sini dimaknai sebagai komunikasi yang menggunakan symbol atau pesan verbal 
yakni semua jenis symbol yang menggunakan satu kata atau lebih. Hampir semua rangsangan wicara yang kita sadari termasuk ke dalam kategori pesan verbal disengaja, yaitu usaha-usaha yang dilakukan secara sadar untuk berhubungan dengan orang lain secara lisan. Dalam hubungan yang terjadi antara kyai dan santrinya, komunikasi verbal terjadi setiap hari saat sang kyai mengajar dalam kelas atau mengobrol bersama membicarakan hal-hal di luar pengajian. Tema yang dibahas bisa bermacammacam, mulai dari permasalahan Negara hingga masalah pertandingan sepak bola.

Selain komunikasi verbal, komunikasi non verbal juga terjadi antara keduanya. Meski tanpa kata, para kyai biasanya mengekspresikan berbagai makna lewat mimik juga sikapnya. Sebagaimana Rakhmat (2008) menyebutkan bahwa komunikasi non verbal dalam komunikasi interpersonal dapat terlihat dari petunjuk proksemik (studi tentang pengguunaan jarak dalam menyampaikan pesan), petunjuk kinesik (gerakan), petunjuk wajah (mimik wajah), dan petunjuk artifaktual (meliputi segala macam penampilan: kosmetik yang dipakai, tas, sepatu, baju, pangkat dan atribut lainnya) ${ }^{3}$. Kaitannya dengan hal ini banyak sekali hal-hal menarik yang bisa diamati dalam komunikasi non verbal kyai kepada santri dan santri kepada sang kyai. Misalnya saja pengalaman pribadi yang dialami Syihabuddin yang menjadi pengasuh Pesantren Sukahideng Tasikmalaya, Jawa Barat. Syihabuddin mengaku bahwa ketika ia menjadi santri dahulu, ia dan santri lain sangat dekat dengan sang kyai. Syihabuddin senang sekali mengambil buah-buahan yang ditanam di halaman rumah kyai, biasanya bahkan tanpa meminta ijin terlebih dahulu. Kyai yang jelas-jelas melihat buah di halamannya diambil tampak kalem saja melihat kelakuan santri-santrinya itu. "Biasanya kalau pak kyai diam saja, berarti artinya boleh”, ucap Syihabuddin sambil mengenang kejadian itu. Karena biasanya kalau tidak boleh, kyai akan langsung berbicara dan menegur para santri.

Sebaliknya para santri pun berkomunikasi non verbal dengan kyai. Terutama ketika pengajian berlangsung. Jika tiba saatnya pelajaran yang membahas kitab-kitab yang susah dimengerti atau ustadz yang mengajar adalah ustadz yang tidak terlalu menyenangkan dalam mengajar, para santri biasanya terlihat gelisah dan terusmenerus melihat jam dinding, tanda mereka tak betah berlama-lama dalam kelas.

\section{Communication $=$ Content + Relationship}

Content merupakan isi dari apa yang hendak dikomunikasikan sedangkan relationship merupakan apa yang hendak kita bangun dari cara kita menyampaikan pesan. Watzlawick menyatakan bahwa dalam sebuah proses komunikasi apa yang hendak disampaikan memang penting namun bagaiman kita menyampaikan juga tidak kalah penting karena menjadi tanda dari relasi macam apa yang hendak kita bangun. Kadangkala masing masing bagian dari system tidak menyadari bahwa cara mereka menyampaikan sebuah pesan akan menyakiti anggota yang lain dan hal

\footnotetext{
${ }^{3}$ Diskusi lebih lengkap tentang komunikasi non verbal lihat Rakhmat, (hlm 82-89)
} 
ini pula lah yang dapat menyebabkan system mengalami disfungsi.

Cara-cara menyampaikan pesan antara kyai dan santri sangat kental dengan ajaran yang diajarkan dalam pengajian-pengajian sehari-hari berdasarkan kitab Ta'lim Al Muta'alim4 yang dipelajari setiap hari. Bagaimana hormat dan cintanya para santri pada kyai mereka, terlihat dari bagaimana mereka berkomunikasi sehari-hari. Maka tidaklah heran betapa merendahnya seorang santri di depan kyai bahkan terkadang dalam berkomunikasi para santri sampai tidak berani untuk langsung menatap wajah dari kyai. Setiap bertemu selalu menunduk dan mencium tangan kyai. Juga penghormatan yang besar kepada keluarga kyai, khususnya pada putra-putrinya yang dianggap ikut mewarisi symbol kewibawaan cultural (Muzadi, 1999).

Dalam berkomunikasi dengan kyai nya, para santri akan selalu memilih dan menggunakan bahasa halus (krama- dalam bahasa Jawa) dengan intonasi yang lembut dan gesture yang sangat sopan. Sebagai murid, santri dalam pondok pesantren modern di Tasikmalaya sangat menghormati kyai nya hingga selalu mengawali komunikasi dengan berjabat dan mencium tangan kyai tanda ta'dzim nya pada sang guru. Saking hormatnya, beberapa santri memiliki rasa malu yang sangat besar pada kyai nya hingga tidak berani menatap atau mencoba mengawali obrolan. Sehingga dalam komunikasi yang terjalin, biasanya kyai lebih dominan dalam menginisasi komunikasi yang

\footnotetext{
${ }^{4}$ Ta'lim Al Muta'alim dalam bahasa Indonesia bermakna pembelajaran untuk siswa. Kitab Ta'limul Muta'allim yaitu kitab tentang etika belajar-mengejar yang dipakai hampir semua pesantren (Muzadi, 1999). Kitab yang merupakan
}

terjadi. Kyai pada umumnya tidak terlalu banyak bicara dan langsung "to the point" dalam menyampaikan apa yang dikehendaki. Sebaliknya, dalam menyampaikan suatu maksud, biasanya santri akan lebih banyak mengawalinya dengan basa-basi.

Cerita menarik yang dialami sendiri oleh penulis ketika nyantren dulu adalah tentang bagaimana ta'dzim-nya atau hormatnya santri kepada sang kyai. Para santri hampir selalu mengidolakan kyainya. Layaknya para remaja yang mengidolakan Boyband asal Korea, Suju, para santri selalu bersedia dan bahkan senang hati melakukan apa yang sang kyai minta juga memberikan apa yang kyai senangi. Contoh kecil adalah bagaimana para santri selalu berebutan untuk menyediakan minuman kesukaan sang kyai atau ustadz. Selain karena ingin menyenangkan hati sang guru, si penyedia minuman juga bisa mendapat berkah yang tak terkira harganya: sisa air minum ustadz. Lebih seru lagi yang terjadi di kelas pengajian santri pria. Ketika ustadz mengakhiri pengajian dan mulai beranjak dari tempat duduknya, para santri pria berbondong-bondong untuk berebut sisa air minum yang masih ada dalam gelas ustadz atau puntung rokok yang masih mengepul dari asbak.

Hal tersebut tidak lain sebagai bentuk hormat dan cinta kepada kyai, guru yang telah memberi ilmu agama dan pengetahuan hidup kepada para santri. Santri beranggapan bahwa dengan menghormati guru yang memberi ilmu,

karya dari Syaikh Zarnuji ini merupakan salah satu kitab ulama salaf yang secara tidak langsung mempengaruhi tata pergaulan diantara sesama orang pesantren. 
niscaya ilmu yang diberikan tersebut akan bermanfaat dan barakah. Hal tersebut sesuai seperti apa yang para santri pelajari dalam banyak kelas di pengajian dan sudah banyak terbukti oleh para santri yang sukses setelah meninggalkan pesantren. Hal ini juga sangat berkaitan dengan aksioma selanjutnya yang memperlihatkan perbedaan power yang dimiliki antara santri dan kyai.

3. All communication is either symmetrical or complementary

Ini berkaitan dengan arah komunikasi dalam suatu system. Symetrical berarti proses penyampaian pesan didominasi oleh satu pihak yang didasarkan pada perbedaan kekuatan atau power yang dimiliki. Sedangkan complementary masing masing pihak saling bergantian dan memiliki porsi yang sama dalam memberikan pesan karena didasarkan pada persamaan kekuatan yang dimiliki kedua belah pihak. Melihat apa yang telah dijabarkan oleh Watzlawick diatas maka dapat dipahami bahwa komunikasi menjadi hal yang sangat penting karena menjadi sebuah isyarat bahwa terdapat hubungan yang sedang berlangsung antar bagian system.

Dalam suatu system yang disebut pesantren, biasanya terjadi perbedaan kekuatan yang dimiliki anatara sang kyai dan santrinya. Seperti yang telah tersirat dalam aksioma sebelumnya, kyai memiliki powernya tersendiri terhadap para santri bahkan masyarakat sekitarnya. Kyai yang sebenarnya orang biasa saja, sama dengan kita, diakui memiliki kelebihan ketimbang orang kebanyakan. Di kalangan masyarakat desa atau kampong, orang yang disebut kyai diakui memiliki kelebihan, bukan saja masalah spiritualkeagamaan, melainkan keahlian dan kearifan lain. masyarakat kerap kali mengadukan kegundahan, problema hidup hingga masalah kesehatan kepada sang kyai (Thoha, 2003) ${ }^{5}$. Di masyarakat kota, kehadiran kyai dengan pesantrennya menjadi oase tersendiri. Kelompokkelompok pengajian atau majelis ta'lim sering kali mengundang kyai seperti itu untuk memberikan santapan rohani, mengisi kekosongan dan kegalauan hati mereka akibat rutinitas kerja dan kesumpekan social yang akrab menghinggapi manusia pekerja tipe kota.

Dihadapan para santri kyai adalah sang guru yang patut untuk dihormati, dijunjung dan ditaati. Apa yang diucapkan oleh sang kyai dalam pengajian dan obrolan sehari-hari menjadi suatu aturan yang secara tidak langsung merasuk ke dalam pikiran santri dan menjadi pegangan hidup para santri. Eksistensi kyai tersebut bahkan dalam konteks kebangsaan dan kenegaraan, melengkapi kelebihan dan kekurangan yang terdapat dalam jajaran pemerintahan mulai dari desa hingga tingkat daerah. Karenanya tak heran bila para pejabat desa, kecamatan, kabupaten, propinsi bahkan Negara memerlukan diri untuk meminta nasihat kepada kyai (Thoha, 2003). Dan tentunya masih melekat dalam ingatan kita bahwa Negara kita juga bahkan pernah dipimpin oleh seorang kyai.

4. The nature of relationship depends on how both Parties punctuate the communication sequence

\footnotetext{
${ }^{5}$ Untuk lebih jelas tentang bagaimana power yang dimiliki kyai dulu dan sekarang, lihat Runtuhnya Singgasana Kyai NU hal 15-19
} 
Ini berkaitan dengan aturan yang akan selalu ada dan muncul dari setiap proses komunikasi yang terjadi dalam suatu system. Aturan yang jelas dan tepat akan menghasilkan sebuah komunikasi yang jelas dan dampaknya adalah pada pembangunan relasi yang baik. Sama seperti ketika kita menggunakan tanda baca yang tepat dalam sebuah kalimat untuk menghasilkan sebuah kalimat yang enak didengar ketika dibacakan. Hal yang sering terjadi dalam sebuah system adalah bahwa tidak ada aturan yang jelas yang diterapkan sehingga masing masing bagian kemudian berjalan sesuai kemauannya sendiri.

Aturan tidak tertulis yang ditaaati oleh para santri adalah (seperti yang telah dibahas sebelumnya) harus menunjukkan rasa hormat dan takzim serta "kepatuhan mutlak" kepada kiai dan ustdznya, bukan manivestasi dari penyerahan total kepada orang-orang yang dianggap memiliki otoritas, tetapi karena suatu keyakinan atas kedudukan guru sebagai penyalur kemurahan (barokah) Tuhan yang dilimpahkan kepada murid-muridnya, baik ketika hidup di dunia maupun di akherat.

Lebih lanjut, Syaikh Zarnuji (2007) mengatakan, menurut ajaran Islam, murid (santri) harus menganggap guru atau kyai seperti ayah kandungnya sendiri, sebagaimana dikatakan dalam sebuah hadits Nabi Saw: "Dan sesungguhnyalah, orang yang mengajarmu walaupun hanya sepatah kata dalam pengetahuan agama adalah ayahmu menurut ajaran Islam”. Hadits ini memberikan justifikasi bahwa apabila santri tidak taat dan patuh pada kiainya berarti secara terang-terangan telah menyalahi apa yang telah dianjurkan oleh baginda Rasul Muhammad Saw.
Berdasarkan korpus resmi ala pesantren, seperti dijabarkan dalam kitab Ta'lim Al-Muta'allim dan kitab-kitab sejenisnya yang memberikan kontribusi pada sistem nilai yang dianut warga pesantren, kemudian diintrodusir sedemikian rupa dalam praktek-praktek kehidupan santri baik dalam bentuk konvensi-konvensi atau menjadi teknikteknik disipliner sehingga menjadi tatanan etis yang mengatur hubungan kiai dan santri. Yang terus dipelihara (reproduksi), kemudian disosialisasikan dari waktu ke waktu, dari satu generasi ke generasi berikutnya dan akhirnya terinternalisasi pada diri setiap santri.

Melalui cara itulah tertib social atau aturan relasi di lingkungan pesantren bisa ditegakkan. Sedangkan tindakan apapun yang mencoba menyimpang darinya akan dicap indisipliner dan pantas mendapatkan sangsi (ta'zir) atau dikenakan denda. Adapun sangsi yang ada bisa dalam bentuk sangsi moral, sosial ataupun berupa sangsi fisik, seperti cukur rambut, membersihkan selokan, dan untuk kasus pelangaran yang parah bisa dipulangkan kepada orang tua.

\section{PENUTUP}

Di kalangan masyarakat santri, figur kiai, secara umum kerap dipersepsikan masyarakat sebagai pribadi yang integratif dan merupakan cerminan tradisi keilmuan dan kepemimpinan, 'alim, menguasai ilmu agama dan mengedepankan penampilan perilaku berbudi yang patut diteladani umatnya. Semakin tinggi tingkat kealiman dan rasa tawadlu' kiai akan semakin tinggi pula derajat penghormatan yang diberikan santri dan masyarakat. Sebaliknya, derajat 
penghormatan umat kepada kiai akan berkurang seiring dengan minimnya penguasaan ilmu dan rendahnya rasa tawadlu' (rendah hati) pada dirinya, sehingga tampak tak berwibawa lagi dihadapan umatnya

Dalam hubungan sistem pesantren pun juga pasti akan sering muncul masalah. Bagaimanapun, arus modernisasi sedikit banyak membawa pergeseran pada peran kyai dan santri di pesantren sehingga kultur yang selama ini tumbuh subur kemudian mengalami degradasi akibat perkembangan global.

Perubahan relasi kyai-santri dapat kita lihat dalam ketundukan seorang santri yang mulai berkurang sebagai akibat oleh bergesernya peran kyai di dalam pesantren maupun masyarakat. Sosok kyai yang dahulu disegani dan berpengaruh karena memiliki kharisma yang jarang dimiliki orang lain, mulai bergeser ketika mereka merambah ke wilayah politik dengan ikut berperan dalam kegiatan politik praktis. Pergeseran antara anggota system ini tentunya berdampak pada system itu sendiri yakni pesantren dan system yang bersinggungan dengannya. Pesantren yang merupakan lembaga pendidikan dan keagamaan ini seakan telah ditakdirkan tidak terlepas dari konstelasi politik yang melingkupinya. Hal tersebut bahkan telah terlihat pada periode awal kemunculan pesantren di jaman Walisongo. Kontak dunia pesantren dan dunia politik mulai terjadi ketika Sunan Ampel diangkat menjadi penasihat Raja Brawijaya dan kemudian menjadi penasihat Sultan Demak, lalu diteruskan Sunan Giri, yang

\footnotetext{
${ }^{6}$ Ahlul haali wal'aqdi adalah orang yang memiliki kapasitas dan kapabilitas mewakili lembaga, pun juga pribadi yang dipandang cakap untuk
}

menjadi Ketua Dewan Ahlul haali wal'aqdi ${ }^{6}$ (Thoha, 2003).

Pada sisi yang lain, seiring dengan demokratisasi di Indonesia dan kesempatan pendidikan yang tinggi oleh santri, banyak komunitas santri yang mulai tercerahkan. Hal ini bisa kita lihat dari cara berpikir mereka yang semakin kritis, independen dan kreatif. Hal ini tenyata berimbas terhadap hubungan kyai-santri yang tidak lagi seperti dahulu di mana saat ini santri telah berani mengkritisi apapun yang dilakukan kyainya yang dianggap melenceng.

Kharisma yang dianggap sebagai senjata ampuh untuk mempengaruhi santri juga pada tataran tertentu tidak lagi menemukan relevansinya pada saat sekarang. Sehingga praktis, kyai sekarang sudah mulai kehilangan pengaruhnya akibat perannya dalam politik praktis. Puncaknya adalah ketika kyai generasi paruh abad ke-20 menjadi bagian dari elite pemerintahan. Misalnya menjelang Pemilu 1999 ketika para kyai mendukung berdirinya Partai Kebangkitan Bangsa (PKB), pesantren dan (sebagian) kyai memobilisir umat dan santrinya untuk terlibat langsung dalam kancah politik praktis. Lebih-lebih ketika K.H Abdurrahman Wahid (Gus Dur) berhasil menduduki kursi RI 1, posisi pesantren semakin terpola dan terpolitisir. Dan tatkala Gus Dur diturunkan dari kursi kepresidenan, dunia pesantren seakan mengalami kegamangan dan kegoyahan eksistensi (Thoha, 2003). Konflik GusdurMuhaimin dalam tubuh PKB juga bisa kita analogikan sebagai salah satu contoh

memecahkan masalah social dan kemasyarakatan lihat (Thoha, 2003) 
melenturnya hubungan kyai-santri (Fatkhuri, 2008).

Disfungsi dari anggota-anggota dalam system ini sesungguhnya sudah diramalkan oleh Watzlawick dalam teori interactional view-nya. Watzlawick beranggapan bahwa ketika suatu system keluarga telah terbentur pada disfungsi system dimana satu sama lain saling menyalahkan akibat komunikasi yang tidak berjalan, perlu adanya suatu proses yang ia namakan sebagai reframing. To reframe means to change the conceptual and/ or emotional setting or viewpoint in relation to which a situation is experienced and to place it in another frame which fits the "facts" of the same concrete situation equally well or even better, and thereby changes its entire meaning (Griffin, 2006).

Watzlawick memetaforakan reframing dengan proses bangun dari mimpi buruk. Dalam mimpi buruk mungkin kamu lari, melompat, dan melakukan berbagai untuk membuat situasi lebih baik, tapi tak ada sesuatu yang berubah, tak ada apapun yang terjadi. Maka itu pula lah yang perlu dilakukan oleh anggota system dalam pesantren. Berdasarkan realitas yang telah dipaparkan di atas, kiranya reposisi pesantren menjadi suatu yang niscaya. Pesantren harus kembali pada fungsi awal, tetapi bukan berarti pesantren dan kyai meninggalkan atau mengabaikan amanah kepemimpinan dunia, sebagaimana memang Rasulullah SAW sendiri, menurut
Nasr dalam Thoha (2003), memegang dua otoritas yakni sebagai pemimpin keagamaan dan sebagai pemimpin pemerintahan.

Reposisi pesantren yang didukung dengan santri dan kyai sebagai anggota sistemnya, akan memberikan nilai lebih pada dunia pesantren itu sendiri, dalam rangka melaksanakan visi dan misi pesantren sebagai sebuah lembaga social dan keagamaan yang bercita-cita mewujudkan kehidupan yang penuh rahmat. Pesantren, dengan itu, bukan hanya harus memperkuat basis keilmuan tapi juga basis keummatan. Basis keilmuan disini artinya pentingnya pesantren melakukan reinterpretasi atas keilmuan pesantren yang dilaksanakan selama ini. Pesantren perlu kiranya mempertimbangkan tawaran-tawaran pemikiran yang disampaikan oleh para pemikir islam kontemporer tanpa meninggalkan apresiasi atas basis keilmuan tradisional. Sedangkan basis keummatan yang dimaksudkan adalah menjadikan ummat sebagai manusia merdeka yang independen sehingga memilki kemandirian dalam berpikir, bersikap dan bertindak. Kemandirian ini sangat penting demi keberdayaan umat itu sendiri dalam mengatasi problem yang ada dan juga dalam eksistensinya sebagai warga Negara. 


\section{DAFTAR PUSTAKA}

\section{Buku:}

Dhofier, Zamakhsyari (2005). Tradisi Pesantren. Bandung: Mizan

Griffin, E.M. (2006). A First Look At Communication Theory. Singapore: McGraw-Hill

Harits, Busyairi (2010). Islam NU, Pengawal Tradisi Sunni Indonesia. Surabaya: Penerbit Khalista

Luthfiani, Fia Silfia (2008). Hubungan Antara Motivasi Berprestasi dengan Kualitas Attachment dengan Ibu Pada Santri Pondok Modern Tingkat Pertama di Kota-Kabupaten Tasikmalaya

Mulyana, Deddy (2007). Ilmu Komunikasi, Suatu Pengantar. Bandung : Remaja Rosda Karya

Muzadi, Hasyim (1999). Nahdlatul Ulama, di Tengah Agenda Persoalan Bangsa. Jakarta : Logos

Pearson et al (2003). Human Communication. Singapore: McGraw-Hill

Rakhmat, Jalaluddin (2001). Metode Penelitian Komunikasi. Bandung : Remaja Rosda Karya
Rakhmat, Jalaluddin (2008). Psikologi Komunikasi. Bandung : Remaja Rosda Karya

Thoha Zainal Arifin (2003). Runtuhnya Singgasana Kiai NU, Pesantren dan Kekuasaan: Pencarian Tak Kunjung usai. Yogyakarta: Kutub

West, Richard \& Turner, Lynn.H. (2010). Introducing Communication Theory, Analysis and Application. Singapore: McGraw-Hill

Wood Julia T. (2010). Interpersonal Communication, Everyday Encounters (6 $6^{\text {th }}$ eds.). USA: Wadsworth Cengage Learning

Zarnuji, Syaikh (2007), Terjemah Ta'lim Muta'lim oleh Ali As'ad. Yogyakarta: Menara Kudus

\section{Internet}

Fatkhuri, 2008, Menakar Hubungan KyaiSantri.http://citizennews.suaramerd eka.com

http://www.colorado.edu/communication Lmetadiscourses/Theory/watzlawic/ http://www.tasikmalayakota.go.id. 